TAPROBANICA, ISSN 1800-427X. April, 2009. Vol. 01, No. 01: pp. 36-38.

(C) Taprobanica Nature Conservation Society, 146, Kendalanda, Homagama, Sri Lanka.

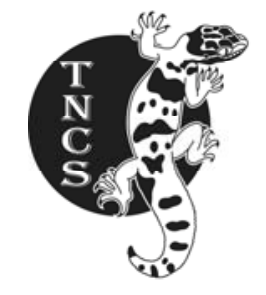

\title{
AN OBSERVATION OF Vanellus indicus BODDAERT, 1783 (AVES: CHARADRIIDAE) FEED ON AN EXOTIC Laevicaulis altae FERUSSAE, 1821 (GASTROPODA: VERONICELLIDAE) AT A HUMAN HABITATION IN SRI LANKA
}

Submitted: 12 January 2009, Accepted: 15 January 2009

\author{
W. Madhava S. Botejue
}

Taprobenica Nature Conservation Society, 146, Kendalanda, Homagama, Sri Lanka

E-mail: madhavabotejue@gmail.com

\begin{abstract}
Red-Wattled Lapwing is a common resident bird distributed throughout Sri Lanka. Laevicaulis altae is an exotic land slug found in home gardens and cultivations in the lowland wet zone and intermediate zone. $L$. altae and other exotic snails and slugs are pests, which is a serious and growing problem in Sri Lanka. This observation describes the behaviour of Red-Wattled Lapwing feeding on the exotic land slug at the premises of the Open University of Sri Lanka, Colombo.
\end{abstract}

Key Words: Red-Wattled Lapwing, Laevicaulis altae, exotic slug, feeding behaviour, predation, Sri Lanka.

\section{Introduction}

Red-Wattled Lapwing, Vanellus indicus Boddaert, 1783 is a common resident bird distributed throughout the edges of tanks, dry paddy fields and open lands near water bodies in the low country and lower hills of Sri Lanka (Ali \& Ripley, 1980; Harrison, 1999; Henry, 1998; Legge, 1983). This bird is about the size of a domestic pigeon with a black, white and bronze-brown coloration and long, slender yellow legs. The most distinguishable character of this bird is the fleshy red wattle in front of the eye and the red ring around the eye. Sexes are alike (Ali \& Ripley, 1980; Harrison, 1999; Henry, 1998; Legge, 1983). This species take most of its food on dry ground, which consists of ground dwelling insects like beetles, grasshoppers, termites and ants, insect larvae like caterpillars and worms, mollusks, aquatic insects as well as vegetable matter (Ali \& Ripley, 1980; Henry, 1998; Legge, 1983). It feed casually during the day, but feeds more actively in the early mornings, evenings and 
throughout the night, especially when moonlight (Ali \& Ripley, 1980; Harrison, 1999).

Laevicaulis altae Ferussae, 1821 is an exotic land slug found in home gardens and cultivations in the lowland wet zone and in the wetter parts of intermediate zone (Raheem \& Naggs, 2006; Priyadarshana, 1998). This species prefers shady damp places, often seen around wells and ponds, on slippery stones and under damp dead leaves (Priyadarshana, 1998).

On 14 ${ }^{\text {th }}$ May 2008 between 11:35 hr and 11:55 hr I observed a mature Red - Wattled Lapwing feeding on an exotic land slug L. altae at the premises of the Open University of Sri Lanka (OUSL). OUSL $\left(6^{\circ}\right.$ $53^{\prime} 10^{\prime \prime} \mathrm{N}$ and $79^{\circ} 52^{\prime} 60^{\prime \prime} \mathrm{E}$; alt. $10 \mathrm{~m}$ ) is situated about $6 \mathrm{~km}$ from the Colombo city in Colombo District in Western Province of Sri Lanka. The vegetation resembles home gardens and the "Kirulapona" canal runs along the west, northwest border of the location. The ground was covered with grass and the canopy cover was about $20 \%$. The observations were made by the naked eye without any disturbances to the bird.

First the bird was observed on the ground foraging about $5 \mathrm{~m}$ away from me. The temperature and the humidity at that time were $31{ }^{\circ} \mathrm{C}$ and $76 \%$ respectively. The weather was sunny. At once the bird dipped forward steeply and caught some thing, which was on the grass. Then it moved about $3 \mathrm{~m}$ towards me in an irregular zigzag manner. It was holding a large $L$. altae crosswise at the tip of the bill (Fig. 01). Then the bird kept the slug on the ground and looked around vigilantly for about 20 seconds. After that the bird rubbed the slug on the grass using its bill for about 1 minute, looking up at regular intervals. Then it again took up the slug in the bill and looked around vigilantly for about another 2 minutes. After that it moved away about 2 $\mathrm{m}$ and kept the slug on the ground. Then the bird rubbed the slug on the grass for about another 2 minute, looking around at regular intervals. Likewise it repeated the same action for three times. Then the bird moved about another $1 \mathrm{~m}$ and swallowed the slug. Then the bird foraged the surrounding about 5 minutes until a domestic dog disturbed the bird. Hence the bird ran about $5 \mathrm{~m}$ and flew away.

According to my observation Red-wattled Lapwings are seemed to be unaccustomed in feeding on slugs. The bird seemed to have some hesitation about feeding on slugs, because it took about 15 minutes to devour a L. altae. I assume that the reason for the bird to rub the slug on the grass is to wipe off the mucous produce by it. Because the mucous produced by slugs may have a defensive function. It may be distasteful to the predator or it may adhere to the mouthparts of the predator and may thus hamper its attack on the slug (Dinarzarde Raheem, August 2008, personal communication). According to Richter, 1980 in Ariolimax columbianus the caudal mucus plug covers the caudal pit which serves as a defense mechanism. Therefore I assume that L. altae also demonstrate the same mechanism. The previous literature also explains the vigilant behaviour of the Red - wattled Lapwing (Ali \& Ripley, 1978; Henry, 1998). L. altae and other exotic snails and slugs are pests for native biodiversity, which is a serious and growing problem in Sri Lanka (Naggs \& Raheem, 2002; Raheem \& Naggs, 2006). If the Red - wattled Lapwing is a common predator of the L. altae, it will be helped to control the spreading of this introduced slug.

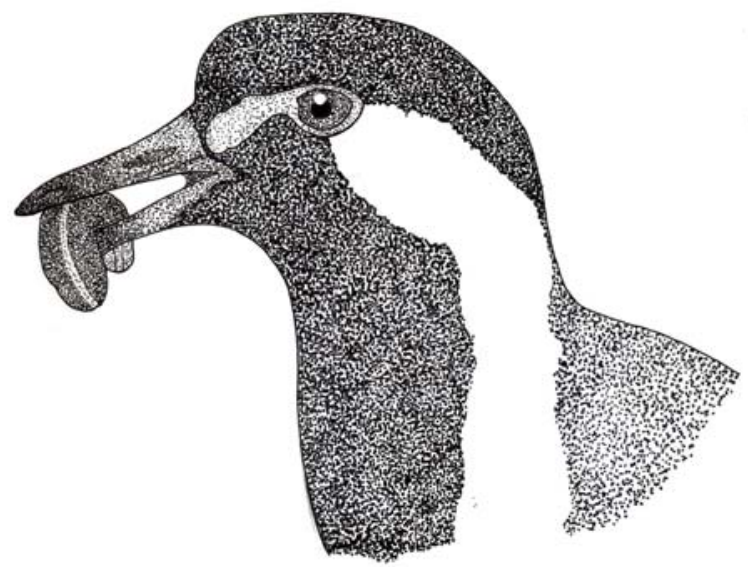

Fig. 01: Red-wattled Lapwing is holding a large L. altae crosswise at the tip of the bill.

\section{Acknowledgements}

I wish to thank Sujan Henkanaththegedara, M. M. Bahir and anonymous reviewers for their valuable comments and reviewing the manuscript. I would like to thank Dinarzarde Raheem (BMNH) for valuable comments and helped improve the document. I also wish to thank my colleagues at the OUSL for supporting the field observation.

\section{Literature Cited}

Ali, S. and S. D. Ripley, 1980. Handbook of the Birds of India and Pakistan, Vol. 02, Second edition. Oxford University Press, New Delhi: 347. 
Harrison, J. and T. Worfolk, 1999. A Field Guide to the birds of Sri Lanka. Oxford University Press, Oxford: 219.

Henry, G. M., 1998. A guide to the birds of Sri Lanka, Third Edition: revised \& enlarged by T. W. Hoffmann, D. Warakagoda and U. Ekanayake. Oxford University Press, London and K. V. G. de Silva \& Sons, Kandy: 488.

Legge, W. V., 1883. A history of the birds of Ceylon, Second edition. Tisara Prakashakayo, Dehiwala, Sri Lanka. 1624.

Naggs, F. and D. Raheem, 2002. Sri Lankan snails. The Natural History Museum, London, UK.

Priyadarshana, T. G. M., 1998. Land Slugs of Sri Lanka (Phylum Mollusca, Family Veronicellidae). Sri Lanka Naturalist, 2 (1\&2): 14-15.

Raheem, D. and F. Naggs, 2006. An Illustrated Guide to the Land Snails of Sri Lankan Natural Forest and Cultivated Habitats. The Natural History Museum, London: 6.

Richter, K. O., 1980. Movement, defense and nutrition as functions of the caudal mucous plug in Ariolimax columbianus. Veliger, 23: 43-47. 